\title{
EARLY LATE PLIOCENE PALEOKARSTIC FILLINGS PREDATING THE MAJOR PLIO-PLEISTOCENE EROSION OF THE QUERCY TABLE, SW-FRANCE
}

\author{
POZNOPLIOCENSKE PALEOKRAŠKE ZAPOLNITVE IZ ČASA \\ PRED GLAVNO PLIO-PLEISTOCENSKO EROZIJO PLANOTE \\ QUERCY, JUGOZAHODNA FRANCIJA
}

\author{
Jean-PIERRE AGUILAR ${ }^{1}$, Jacques MICHAUX², Thierry PÉLISSIÉ ${ }^{3}$, Bernard SIGÉ ${ }^{4}$
}

\begin{abstract}
UDC 903.5:569.32(118.2)(44)

Jean-Pierre Aguilar, Jacques Michaux, Thierry Pélissié \& Bernard Sigé: Early late Pliocene paleokarstic fillings predating the major Plio-Pleistocene erosion of the Quercy table, SWFrance

Early late Pliocene rodent tooth remains, have been found in situ within Quercy paleokarstic fillings. They provide evidence of a sedimentary episode related to a high Pliocene marine level ca 3.5 Ma ago, that illustrates the situation predating the regional erosion phase and setting up of the hydrographic system. Key words: Rodents, Plio-Pleistocene erosion, Quercy, SWFrance.
\end{abstract}

Izvleček UDK 903.5:569.32(118.2)(44) Jean-Pierre Aguilar, Jacques Michaux, Thierry Pélissié \& Bernard Sigé: Poznopliocenske paleokraške zapolnitve iz časa pred glavno plio-pleistocensko erozijo planote Quercy, jugozahodna Francija

V paleokraških zapolnitvah Quercyja smo našli ostanke zob glodalcev iz zgodnjega dela poznega pliocena. Ostanki so dokaz o sedimentnem obdobju povezanem $\mathrm{z}$ visoko gladino morja pred približno 3,5 milijoni let. Najdišče odraža stanje pred regionalno erozijsko fazo in vzpostavitvijo hidrografskega sistema. Ključne besede: Glodalci, plio-pleistocenska erozija, Quercy, JZ Francija.

\section{INTRODUCTION}

The underground paleokarstic network system in the Quercy area (Fig. 1) was revealed at the end of the19th century, along with the extended phosphate ore mining on this Jurassic limestone plateau. A long karstic evolution began as soon as the emergence of the platform during Late Cretaceous times.

This evolution consists, first in the elaboration of the underground net systems, then in a long polyphased process of filling - emptying the karstic voids, according to the up and down base level changes that occurred almost continuously during the first half of the Tertiary era. The filling sediments are mostly vadose clay deposits, the various ages of which being established from the study of their fossil vertebrate contents (for latest accounts see Pélissié \& Sigé 2006). Then, since latest Oligocene times, the Quercy platform was covered with prograding lacustrine sediments of the Aquitaine Basin. Finally, the whole structure was strongly worn down by the socalled Plio-Pleistocene erosional phase: the previously deep underground system became closer to the surface, and was exposed both to erosion and widening, but also Plio-Pleistocene fillings occurred as shown by the fossils they include (Crochet et al. 2006). Among the latter are rare Late Pliocene and Plio-Pleistocene tooth specimens.

${ }^{1}$ Institut des Sciences de l'Evolution (UMR 5554-CNRS) Université Montpellier 2, CC 064, Place E-Bataillon, F- 34095 Montpellier, cedex 5. (aguilar@isem.univ-montp2.fr)

2 Institut des Sciences de l'Evolution \& EPHE (UMR 5554-CNRS) Université Montpellier 2, CC 064, Place E-Bataillon, F-34095 Montpellier, cedex 5. (michaux@isem.univ-montp2.fr)

${ }^{3}$ Phosphatières du Quercy, 85 mas de Couderc, F-46260 Limogne en Quercy. (thierry.pelissie@wanadoo.fr)

${ }^{4}$ UMR 5125 PEPS CNRS, France; Université Lyon 1, Campus de la Doua, Bâtiment Geode 69622 Villeurbanne Cedex, France. (bernard.sige@univ-lyon1.fr)

Received/Prejeto: 24.08.2007 


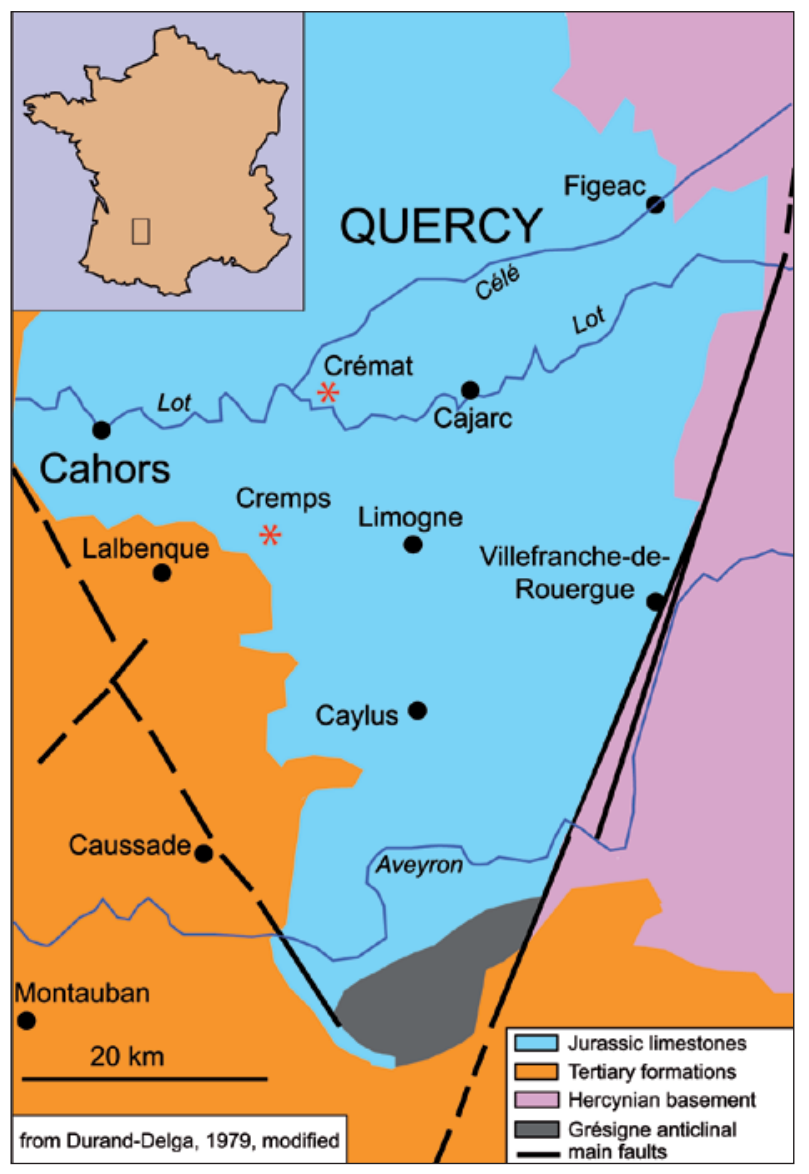

Fig. 1: Geological setting and localization of the discuted structures in the Quercy, SW France.

Such remains result from sub-erosion, or more probably from contamination over the underlying Tertiary fillings that occurred when the pits were quarried from top to bottom (ibid, p. 86-87). Since they sustain our new data, these fossils are reported herein (Fig. 3).
In spite of long lasted fieldwork in Quercy and high number of recorded localities (over 150 for the whole paleokarstic area), until now not a single in situ filling was reported to the Pliocene period. The present paper documents such a case of Pliocene fillings within the Quercy

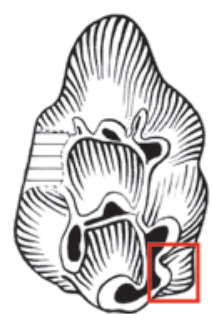

1

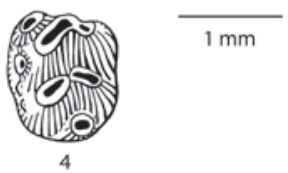

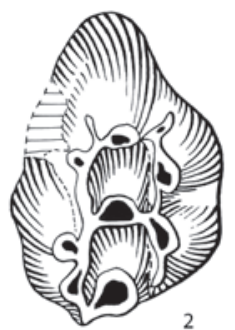

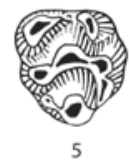

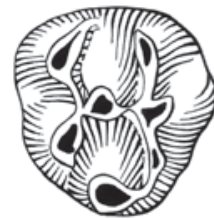

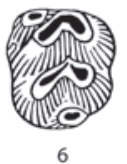

Fig. 3 - Murid rodents - molar teeth from the Quercy early Late Pliocene and Plio-Pleistocene localities :

Vielase-P, Stephanomys cf. donnezani : 1 - M1 sin. $(2,88 x$ 1,92);

Pech Desse-P, Stephanomys cf. donnezani : 2 - M1 dex. (3,04x 2,09), 3 - M2 sin. (2,03 $\times 1,96)$;

Cuzal P-Q, Apodemus sp. : 4 - $m 2$ sin. $(1,27 \times 1,17)$;

Trifon P-Q, Apodemus cf. dominans : 5 - M2 sin. $(1,17 \times 1,13)$, $6-m 2 \sin .(1,18 \times 1,09)$.

Cremps filling $n^{\circ} 5$, : locates the recognized fragment (cusp t9) of Stephanomys $c f$. donnezani

All figures X 20, drawn by J.-P. Aguilar and L. Meslin.

paleokarst, and addresses its bearing for the geodynamic and geomorphological evolution of the area.

\section{DESCRIPTION}

In addition to natural erosion, various human works resulted in sections of the Jurassic limestone as well as sections of natural fillings. In the central western part of the phosphoritic area, near Cremps village (Fig. 1), a road passing through a meandriform dry valley directed toward the river Lot had its rocky northern side cut for enlargement (Fig. 2).

This results in sections of several closely spaced karstic gullies with their natural fillings. About $1 \mathrm{~m}$ wide, some of them visible on the ground surface, the gullies appear as digits of a major channel (Fig. 2). The gullies share similar filling sediments made of brown and greenish sandy clay, including centimetric doll concretions. These sediments fully lack the iron pisoliths that are common in the Quercy Paleogene fillings. The fine sandy residues obtained by washing and sieving sediments contain millimetric bone and tooth fragments, among which enamel blades of rodent incisors are dominant, along with rare molar fragments. These fossils occur in somewhat varied proportion within four of the five exposed 

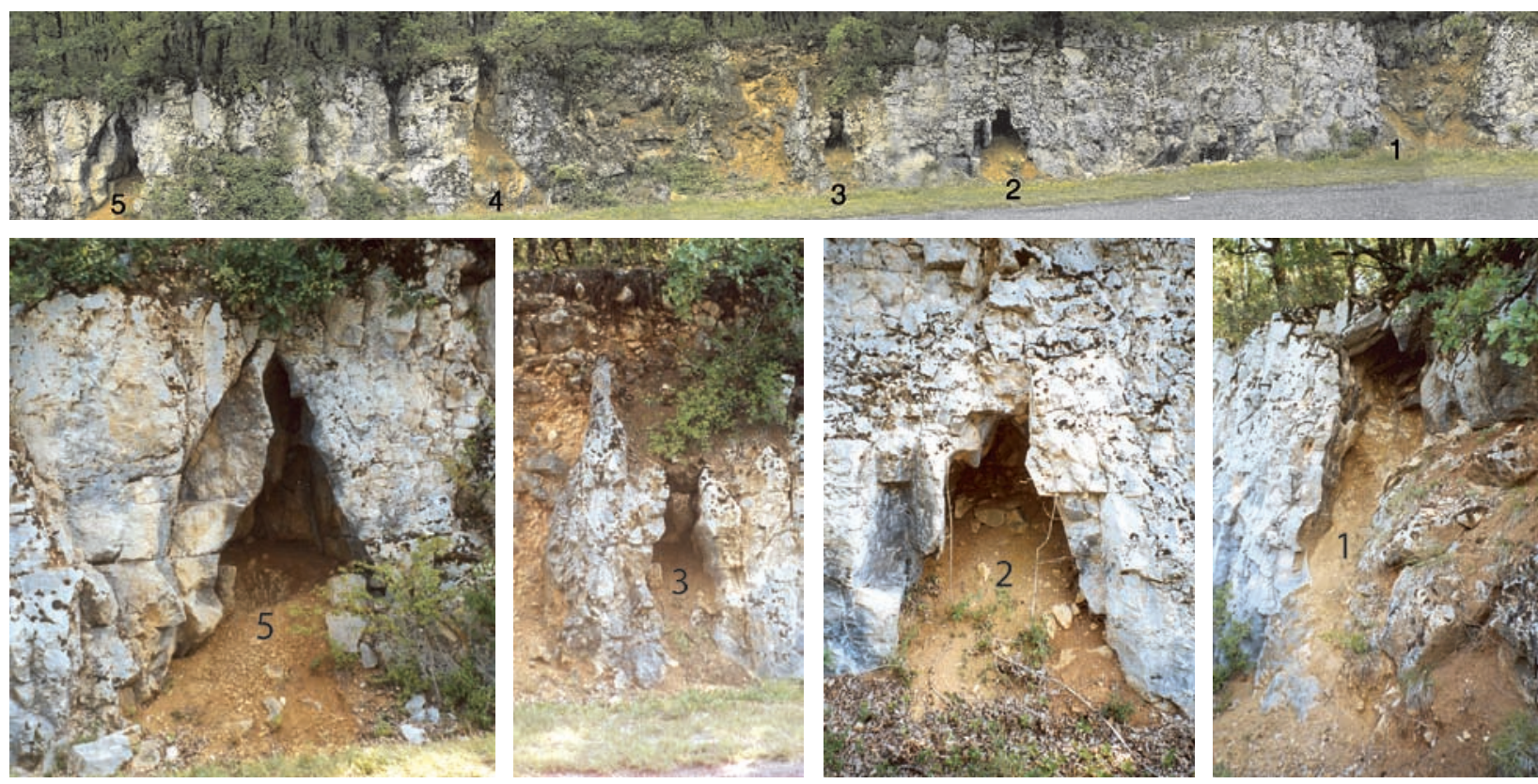

Fig. 2: Cremps 1 to 5 paleokarstic fillings views (photos Th. P. \& B. S., improved J.-P. A.).

filling sections. A long transportation within heavy sandy mud likely explains such a preservation state immediately prior to the destruction of the teeth. Such sediments much probably have filled again emptied conducts of the Paleogene paleokarst.

\section{PALEONTOLOGY}

As mentioned above, not a complete tooth could be found from the sampled four channels, but only fragments. Because of the weak mineralization condition and the tooth type, such remains are difficult to assess as regards their systematic position. Nevertheless, among various fragments, the Cremps 5 sample provided specimens, which we confidently recognized, some as strips of arvicolid rodent molars, and others as murid rodent cusps. The height and shape of one of them, a labial fragment (Fig. 3), allowed us to recognize it as the cusp t 9 of a Stephanomys molar that belongs to a species close to $\mathrm{S}$. donnezani reported from localities as Sète or Mont-Hélène in France (Aguilar et al., 1985, Bachelet 1990). Let's recall that three isolated S. donnezani molars (Fig. 3, $\mathrm{n}^{\circ} 1-3$ ) and three Apodemus molars (Fig. 3, $\mathrm{n}^{\circ}$ 4-6) were previously found within some Paleogene Quercy faunas (Vielase-P, Pech-Desse-P, Cuzal-P-Q, Trifon-P-Q) as resulting from mining contamination (Crochet et al., 2006).
The association of Stephanomys donnezani with an arvicolid characterizes the MN 15 zone (cf. de Bruijn et al. 1992), the corresponding time interval is short and extends from the end of the Lower Pliocene to the beginning of the Late Pliocene; an age ca 3.5 Ma can be suggested (Aguilar et al., 1999). On the Mediterranean border, this period corresponds to the end of the Roussillon Basin filling, shortly followed by the progressive retreat of the Pliocene sea. 


\section{GEOMORPHOLOGICAL INFERENCE}

Wherever occurring, caves as well, the deposition of sediments generally relates to high marine base levels. For the period considered here, the corresponding one is likely the early Piacenzian high level (Haq et al., 1987). In the Aquitaine area, the related Pliocene marine levels occur far away from the current coast, with the exception of the Redonian deposits of the Loire-Atlantique region (Alvinerie et al., 1992). Once admitting that the Cremps fillings imply a Pliocene high sea level, we should suppose that the deposits related to this transgressive episode, whatever marine or continental, have been generally removed during the late Pliocene and/or the Pleistocene.

The Cremps fillings need to be considered in their relation to the hydrographic system of the river Lot. According to Astruc et al., (2000), the Lot corridor, as well as those of the other regional rivers (Célé and Aveyron) would have been settled at the very beginning of a late Pliocene to lower Pleistocene uplift phase. If so, the early Late Pliocene Cremps fillings would just precede the setting down of the incipient Lot River into its present place, long before the limestone table was deeply dug and its surface lowered to its present level. The duration of the time interval between the Cremps fillings (ca 3.5 Ma) and the river system setting is open to question. A long gap may separate these fillings from the beginning of the incision of the Lot River, hypothetized at ca $1 \mathrm{Ma}$ as the oldest age (e.g. Simon-Coinçon 1989). From our present data, this incision, along with the planation of the Quercy plateau, could have occurred much earlier. In the course of such a strong erosion process, the Pliocene Cremps fillings as well as the Paleogene cave fillings, initially located very deep under the surface, get closer to it. In many cases their roofs were partly or fully removed (e.g. the Mémerlin cañon). Such evidence much extends the whole vertical original depth of the Quercy phosphate ore pits, down to 150 meters or even more for some of them (e.g. St-Jean-de-Laur, Roqueprune, Coulou).

Fresh water fossils (fish vertebrae) have been reported from rare Quercy fillings, such as the Cremat one (Sigé et al., 1991), ca $2 \mathrm{~km}$ northward of the Lot valley (Fig. 1), in a small pit located at the average altitude of the Quercy plateau. According to its mammal remains, especially the rodents, the Cremat fauna is MN 3 zone, Burdigalian, early Miocene in age, ca $18 \mathrm{Ma}$. Its fish remains indicate the connexion between the past river system and the Cremat karst system. These remains provide evidence of a paleo-Lot then flowing erratically and depositing sediment $150 \mathrm{~m}$ over the present day level, in a way probably similar as regards the other regional rivers. The Cremps fillings (today at $214 \mathrm{~m}$ asl) testify to a high early Late Pliocene base level, still well above the present day one at ca $3.5 \mathrm{Ma}$.

\section{CONCLUSION}

Rodent tooth remains, early late Pliocene in age, have been found in situ within paleokarst fillings near Cremps village, in the median western phosphate ore area of the Quercy. They give evidence of a sedimentary episode related to a high Pliocene sea level predating the incision of the present regional river system. Previously suspected from specimens artificially mixed to some Paleogene faunas, Pliocene deposits occur within the Quercy pale- okarst, as shown by the fossil contents from some fillings near Cremps.

Contributions ISE-M - 2007-065 (CNRS-UMR 5554) \& UMR 125-07.033

Acknowledgments : the authors thank Ms. Laurence Meslin for drawings improvement, M. Michel Legris for english text checking and Prof. Ivan Horacek for helpful lecture. 


\section{REFERENCES}

Aguilar, J.-P., Calvet, M. \& Michaux, J. 1985 : Description des rongeurs pliocènes du Mont-Hélène (Pyrénées - Orientales), nouveau jalon entre les faunes de Perpignan (Serrat d'en Vacquer) et de Sète. Palaeovertebrata, 16, 3, 124-144.

Aguilar, J.-P., Legendre, S., Michaux, J. \& Montuire, S. 1999 : Pliocene mammals and climatic reconstruction in the Western Mediterranean area; In Wrenn, J.H., Suc J.-P. \& Leroy S.A.G. (Eds), The Pliocene, Time of Change. American Association of Stratigraphic Palynologists Foundation, 109-120.

Alvinerie, J., Antunes, M.T., Cahuzac, B., Lauriat-Rage, A., Montenat, C. \& Pujol, C. 1992 : Synthetic data on the paleogeographic history of Northeastern Atlantic and Betic-Rifian basin, during the Neogene (from Brittany, France, to Morocco). Palaeogeography, Palaeoclimatology, Palaeoecology, 95, 263-286.

Astruc, J.G., Cubaynes, R., Durand-Delga, M., Legendre, S., Muratet, B., Pajot, B., Pélissié, T., Rey, J. \& Sigé, B. 2000 : Notice explicative, Carte géol. France (1/50 000), feuille Nègrepelisse (931). Orléans : BRGM, 1112.

Bachelet, B., 1990 : Muridae et Arvicolidae (Rodentia, Mammalia) du Pliocène du Sud de la France: systématique, évolution, biochronologie. Thèse Univ. Montpellier II, 1-199.
Bruijn, H. de, Daams, R., Daxner-Höck, G., Fahlbusch, V., Ginsburg, L., Mein, P. \& Morales, J., 1992: Report of the RCMNS working group on fossil mammals, Reisensburg 1990. Newsletters on Stratigraphy, 26 (2/3), 65-118.

Crochet, J.-Y., Aguilar, J.-P., Astruc, J. G., Boulbès, N., Escarguel, G., Michaux, J., Montuire, S., Pélissié, T., Simon-Coinçon, R. \& Sigé, B., 2006 : Reprises pliopléistocènes du paléokarst quercinois. Strata, 1, 13, p. 85-95.

Haq, B. U., Hardenbol, J. \& Vai, P.R., 1987 : Chronology of fluctuating sea levels since the Triassic. Science, 235, 1156-1167.

Pélissié, Th. \& Sigé, B., 2006 : 30 millions d’années de biodiversité dynamique dans le paléokarst du Quercy. Journées Bernard Gèze. Strata (sér. 1) 13, 1-284.

Sigé, B., Aguilar, J.-P., Marandat, B. \& Astruc, J.G., 1991: Extension au Miocène inférieur des remplissages phosphatés du Quercy. La faune de vertébrés de Crémat (Lot, France). Geobios, 24, 4, 497-502

Simon-Coinçon, R., 1989 : Le rôle des paléoaltérations et des paléoformes dans les socles : l'exemple du Rouergue (Massif Central Français). Thèse Doct. ès Lettres, Paris I, ENSMP, Mémoire des Sciences de la Terre, $n^{\circ}$ 9, $290 \mathrm{p}$. 
